\title{
Effect of Transplanting Date and Harvest Method on Growth and Survival of Three Urban Tree Species in an Arid Climate
}

\author{
Nematollah Etemadi, Rezvan Mohammadi Nezhad, Najmeh Zamani, and \\ Mohammad Mahdi Majidi
}

\begin{abstract}
The major challenges for transplanting trees in arid regions compared to temperate regions are higher mortality and slower rate of establishment. As such, date and method of transplanting can potentially improve survival and establishment as well as subsequent landscape performance of transplanted trees in arid climate. In the present study, three urban species commonly used in the Isfahan, Iran, landscape including eldarica pine (Pinus eldarica Medw.), white mulberry (Morus alba L.), and smoothleaf elm (Ulmus carpinifolia Gled.), were transplanted from January to June 2010, when mean air temperature was less than $10^{\circ} \mathrm{C}$ (early winter), between $10^{\circ} \mathrm{C}$ and $20^{\circ} \mathrm{C}$ (early spring), or more than $20^{\circ} \mathrm{C}$ (late spring). Half of the trees were bare root (BR) and half balled and burlapped (B\&B). White mulberry and smoothleaf elm trees transplanted early in winter had the highest survival percentage over two years. The best survival for eldarica pine was observed in early spring transplanted trees. For all species, survival rate and trunk diameter increase of B\&B trees were significantly greater than BR trees during the first year. Also, the first year's shoot growth and shoot number of pine trees, and dieback on elm trees, were significantly affected by transplanting method. During the second year, tree growth and survival for all species were similar for B\&B and BR trees. Annual shoot growth of eldarica pine and smoothleaf elm trees, but not white mulberry, equaled to nontransplanted trees by the end of third year after transplanting, suggesting a species-specific response for post-transplant establishment in arid climate.

Key Words. Arid Climate; Balled and Burlapped; Bare Root; Cultural Practices; Eldarica Pine; Iran; Isfahan; Morus alba; Pinus eldarica; Relative Growth Rate; Shoot Growth; Smoothleaf Elm; Ulmus carpinifolia; White Mulberry.
\end{abstract}

Rapid urbanization in most developing countries with dry climate have resulted in the loss or cut off a multitude of mature trees present in the way of construction activities. Transplanting landscape-sized trees is the method of choice to counter this loss and to preserve trees that conflict with urban development projects. However, trees cannot easily reestablish in arid and semiarid areas due to adverse weather conditions, such as high temperature, high evapotranspiration, and water shortages (Milton et al. 1994; Zhang et al. 2002). Mortality rate is up to $50 \%$ among newly transplanted urban trees in these areas and is still commonplace during early growing seasons following transplanting (Bainbridge et al. 2001; Hiron and Percival 2012), which increase the expenses associated with the maintenance and replacement of failed trees. In addition to severe environmental conditions, this is due to the difficult growing conditions found in cities and towns, affecting post-transplant growth, vitality, and lifespan of urban trees (Bühler et al. 2007).

Date of transplanting potentially affects tree growth and establishment as it dictates the specific physiological status of plant (e.g., dormancy, leaf drop, bud set, shoot expanding) as well as specific weather conditions (e.g., temperature and moisture, wind, light intensity and quality) that influence root regeneration capacity (Richardson-Calfee and Harris 2005). Autumn and spring are commonly considered as the best times for transplanting most trees and shrubs in climates characterized by wet springs and autumns due to the favorable soils and air temperature conditions and the absence of active shoot growth, all of which minimize the potential for desiccation (Watson and Himelick 1997; Harris and Fanelli 1999; Richardson-Calfee and Harris 2005). Transplanting in dormant season, if the winter soil temperature remains high, provides opportunities for a tree to regenerate its root system prior to shoot growth in springtime (Buckstrup and Bassuk 2000). However, transplanting in the dormant season is not recommended in climates with severe winters (Harris and Fanelli 1999; Richardson-Calfee and Harris 2005). Conversely, spring transplanting before budbreak, usually avoids damages of cold weather. Transplanting when trees are approaching budbreak is associated with carbohydrate drain from roots, which may result in poor root regeneration (Dumbroff and Webb 1978).

Tree species vary in their responses to season of transplanting. While autumn transplanting could improve growth and survival of some species (Harris and Bassuk 1994; Harris et al. 1996; Buckstrup and Bassuk 2000; Harris et al. 2002), spring transplanting may be preferable (Watson et al. 1986; Harris and Bassuk 1994; Buckstrup and Bassuk 2000) or similar (Watson and Himelick 1982; Kelly and Moser 1993; Harris et al. 2001) to autumn transplanting for other species.

Method of transplant affects post-transplant establishment by influencing the volume of root loss during harvesting. Because all of the soil is removed from a bare root tree, shipping and handling costs are lower, resulting in up to $33 \%$ to $50 \%$ cost reduction when compared to B\&B trees (Buckstrup and Bassuk 2003; Sather et al. 2004; Trowbridge and Bassuk 2004). The 
disadvantage of bare root trees is that having lost the protective soil cover, roots are exposed to desiccation (Anella et al. 2008).

Findings of some studies directly comparing bare root and $\mathrm{B} \& \mathrm{~B}$ trees have shown higher mortality in bare root trees (Cool 1975; Sather et al. 2004), while other studies have suggested that if bare root trees transplanted with proper care (roots be dipped in a hydrophilic gel immediately after harvesting and wrapped in a plastic bag to keep the roots moisture), no significant difference could be observed between two methods (Buckstrup and Bassuk 2000; Anella et al. 2008; Jack-Scott 2012). However, B\&B trees had higher growth indices in some studies (Vanstone and Ronald 1981; Ross 2008).

Although transplanting and re-establishment of urban trees in arid and semiarid regions, such as Isfahan province, Iran, is a costly process, the value of returned benefits is great enough to justify the expenses. Furthermore, obtaining information regarding growth and vitality of urban trees in these regions is critically required for maximizing transplanting success and minimizing public expenditure. The objective of the present study was to examine the effect of two different transplanting method (BR versus $\mathrm{B} \& \mathrm{~B})$ as well as transplanting date on growth and survival of three popular urban trees, including eldarica pine (Pinus eldarica Medw.), white mulberry (Morus alba L.), and smoothleaf elm (Ulmus carpinifolia Gled.) in arid and semiarid climate.

\section{MATERIAL AND METHODS}

\section{Study Area and Climatic Conditions}

The experiment was carried out in a two hectare, open field agricultural research center, located at eastern Isfahan, Iran (latitude $32^{\circ} 37^{\prime} 26^{\prime \prime} \mathrm{N}$, longitude $51^{\circ} 44^{\prime} 23$ 'E, altitude 1,566.6 $\mathrm{m})$. According to the climatic information obtained from Iran Meteorological Organization, the study area was classified as cold-arid, with mean monthly temperature ranging from $3.2^{\circ} \mathrm{C}$ in winter to $29.1^{\circ} \mathrm{C}$ in summer. Mean daily temperature may exceed $40^{\circ} \mathrm{C}$ during summer. During the experimental period, mean annual evaporation and rainfall were $1,923 \mathrm{~mm}$ and 125 $\mathrm{mm}$, respectively. Rainfall was not seasonally well distributed and mostly concentrated in the November to May period.

\section{Planting Description and Cultural Practices}

A total of 144 trees of three dominant urban species in Isfahan landscape, including eldarica pine, white mulberry, and smoothleaf elm were selected from streets and boulevards that conflict with roads and subways developing projects and randomly assigned for transplant as BR or B\&B. All trees (48 trees per species) were 7-12 years old, with average trunk diameter of $\sim 9$ $\mathrm{cm}$ (measured $10 \mathrm{~cm}$ above the ground). These trees had been first installed along the streets as container-grown nursery stocks at the age of 2-3 years old. Selected trees were harvested and transplanted from January to June 2010, when daily mean air temperatures were: 1) less than $10^{\circ} \mathrm{C}$ (early winter, when deciduous trees were leafless), 2) between $10^{\circ} \mathrm{C}$ and $20^{\circ} \mathrm{C}$ (early spring, before budbreak), and 3) more than $20^{\circ} \mathrm{C}$ (late spring, during active shoot growth). These periods of time were concurrent with construction activities in Isfahan city. The number of trees for each date of transplanting was not equal but at least eight trees were assigned to each date. Due to the lack of suffi- cient number of trees in late spring, transplanting of smoothleaf elm trees was performed only in early winter and early spring.

Based on the distance from pavements and neighboring structures, trees were dug manually or using a backhoe, with root ball width about 10 times of trunk diameter $(\sim 1 \mathrm{~m})$. Three to four days before harvesting, trees were irrigated in order to facilitate digging operations. Twenty-four trees of each species were bare rooted; their roots were sprayed with a stream of water and then slipped into black plastic bags and kept in shade to maintain moisture. The root balls of 24 remaining trees of each species were wrapped in burlap and tightly laced with wire, so that the root ball was prevented from disintegrating. $\mathrm{B} \& \mathrm{~B}$ and $\mathrm{BR}$ trees were stacked gently in the bed of a dump truck and transported to the experiment site. Transporting distance to the destination site was between 5 and 15 kilometers and all trees were planted the same day they were harvested, without delay or hardening-off process.

Planting holes were dug twice the width and the same depth (about $1 \mathrm{~m}$ ) of root balls, on $4 \mathrm{~m} \times 4 \mathrm{~m}$ rows spacing. After installation, the planting holes were refilled with original, unamended soil (silt loam texture with $\mathrm{pH} 7.9$, EC $2.6 \mathrm{dS} / \mathrm{m}$, and SAR 4.2) and trees were watered immediately. Thereafter, each tree was irrigated via surface irrigation with $150 \mathrm{~L}$ of water every 5 to 10 days, according to the air temperature and seasonal weather conditions. This amount of irrigation water was greater than that of used for trees in the Isfahan landscape but continued until trees established. Trees were in full sun during the day and there was no prevailing wind direction at the site. Weeds were controlled mechanically during the trial. No supplemental fertilization was applied to the trees.

\section{Data Collection}

Percent survival of each species in October of 2010 and 2011 was calculated as the total number of survived trees in each year divided by the initial number of trees. At the same time, four one-year shoots from different cardinal directions were selected at mid-canopy of each tree and average number and length of current-season shoots (shoots that grow during the growing season and are green, flexible, easy to bend, and can be distinguished from last growing season's shoots from the place of bud scales drop), as well as dieback of terminal shoots (dried part of shoots tip) were measured on them. In October of the third year (2012), current-season shoot length of untransplanted trees that was of almost equal size of transplanted trees, were also measured in order to examine trees establishment. Untransplanted trees were in an adjacent field and were in a similar situation to transplanted trees in terms of soil condition and irrigation. No supplemental fertilization was applied to untransplanted trees except in the case of observation of deficiency symptoms.

For broadleaf trees, mean leaf chlorophyll content was measured by averaging SPAD meter (Hansatech Instruments, CL-01, UK) readings from four randomly selected leaves per tree. Leaf chlorophyll content of eldarica pine trees was determined by measuring the absorbance at $663 \mathrm{~mm}$ and $645 \mathrm{~nm}$, after extraction with $80 \% \mathrm{v} / \mathrm{v}$ aqueous acetone (Lichtenthaler 1987).

Relative growth rate for trunk diameter $10 \mathrm{~cm}$ above the soil surface $\left(\mathrm{RGR}_{\mathrm{D}}\right)$ was calculated from June to October 2010 and from June to October 2011, using the conventional formula (Hoffman and Poorter 2002):

RGR D =

$$
\frac{\log _{\mathrm{e}} \mathrm{D}_{2}-\log _{\mathrm{e}} \mathrm{D}_{1}}{\mathrm{t}_{2}-\mathrm{t}_{1}}
$$


where $\mathrm{D}_{1}$ and $\mathrm{D}_{2}$ are tree trunk diameter at first $\left(\mathrm{t}_{1}=\right.$ June 2010/2011) and second $\left(\mathrm{t}_{2}=\right.$ October 2010/2011) measurement times.

\section{Experimental Design and Statistical Analysis}

The experimental design for method of transplanting was randomized complete block design with four blocks and six tree replicates per treatment (B\&B and $B R$ ) per block. Survival data were analyzed using $\chi^{2}$ analysis $(\mathrm{p}<$ 0.05 ) in SPSS ver. 16.0. All other data were analyzed in SAS ver. 9.1 and mean separation was accomplished with Duncan's multiple-range test at the 5\% level of significance. Data for each tree species were analyzed separately.

Due to limitation in providing equal number of trees for each date of transplanting, this factor was not included in the experiment and its impact was assessed only on tree survival using $\chi^{2}$ analysis.

\section{RESULTS}

\section{Effect of Transplanting Date on Tree Survival}

Results showed that percent survival of all three species was significantly affected by transplanting date (Table 1). During the first year, early-spring-transplanted eldarica pine trees showed significantly higher survival than late-spring-transplanted trees. No plants survived when transplanted in early winter. By the second year, a slight decrease was observed in survival of early-spring-transplanted trees, while $13 \%$ of late-springtransplanted trees, which looked to be dead, showed signs of survival (e.g., appearance of new needles from terminal buds) and continued to grow and were therefore considered as survived trees but were not involved in other growth analyses.

Percent survival of early-winter-transplanted white mulberry trees was $100 \%$ in the first year and remained the same in the second year. Percent survival of early-spring- and latespring-transplanted trees was $95 \%$ and $80 \%$, respectively, which declined to $67 \%$ and $70 \%$ by the second year, respectively.

Table 1. Effects of transplanting date on percent survival of transplanted eldarica pine (Pinus eldarica), white mulberry (Morus alba), and smoothleaf elm (Ulmus carpinifolia) trees in the first (2010) and second (2011) years following transplanting. Percent survival was assessed in October of each year.

\begin{tabular}{|c|c|c|c|}
\hline \multirow[t]{2}{*}{ Year/Species } & \multicolumn{3}{|c|}{ Transplanting date } \\
\hline & Early winter & Early spring & Late spring \\
\hline \multicolumn{4}{|c|}{2010} \\
\hline Eldarica pine & $0 \mathrm{c}^{\mathrm{z}}$ & $76 a$ & $25 \mathrm{~b}$ \\
\hline White mulberry & $100 \mathrm{a}$ & $95 \mathrm{~b}$ & $80 \mathrm{c}$ \\
\hline Smoothleaf elm & $39 a$ & $0 \mathrm{~b}$ & - \\
\hline \multicolumn{4}{|c|}{2011} \\
\hline Eldarica pine & $0 \mathrm{c}$ & $70 \mathrm{a}$ & $38 b^{y}$ \\
\hline White mulberry & $100 \mathrm{a}$ & $67 \mathrm{~b}$ & $70 \mathrm{~b}$ \\
\hline Smoothleaf elm & $33 \mathrm{a}$ & $20 b^{x}$ & - \\
\hline
\end{tabular}

${ }^{\mathrm{z}}$ Treatment means within rows in each year followed by the same letter are not significantly different $\left(\chi^{2}\right)$ at $5 \%$ level.

${ }^{\mathrm{y}},{ }^{\mathrm{x}}$ During the second year following transplanting (2011), a number of eldarica pine and smoothleaf elm trees were recovered and involved in survival analysis. See text for more details.

Smoothleaf elm trees were transplanted only in early winter and early spring.
Smoothleaf elm trees showed low ability to tolerate transplanting. During the first year, only 39\% of early-winter-transplanted trees survived, which decreased to $33 \%$ by the second year. However, during the second year, $20 \%$ of early-spring-transplanted trees were recovered by producing epicormic shoots and were involved in survival analysis but not in other growth analyses.

\section{Effect of Transplanting Method on Tree Survival}

Transplanting method had significant impact on survival of all three species in the first year (Table 2). Percent survival of B\&B eldarica pine and smoothleaf elm trees was significantly greater (30\% and 64\%, respectively) than BR trees. The least impact of production method was observed for white mulberry trees, which exhibited the highest percent survival, regardless of treatment. The overall survival of B\&B trees was $67 \%$, compared to $53 \%$ for BR trees. By the second year, however, no significant difference could be observed between $\mathrm{B} \& \mathrm{~B}$ and $\mathrm{BR}$ trees of all species.

Table 2. Effects of transplanting method on percent survival of transplanted eldarica pine (Pinus eldarica), white mulberry (Morus alba), and smoothleaf elm (Ulmus carpinifolia) trees in the first (2010) and second (2011) years following transplanting. Percent survival was assessed in October of each year.

\begin{tabular}{llccc}
\hline & \multicolumn{4}{c}{ Year/Transplanting method } \\
Species & BR & B\&B & BR & B\&B \\
\hline Eldarica pine & $53 \mathrm{~b}^{\mathrm{z}}$ & $69 \mathrm{a}$ & $67 \mathrm{a}$ & $56 \mathrm{a}$ \\
White mulberry & $80 \mathrm{~b}$ & $90 \mathrm{a}$ & $67 \mathrm{a}$ & $74 \mathrm{a}$ \\
Smoothleaf elm & $25 \mathrm{~b}$ & $41 \mathrm{a}$ & $25 \mathrm{a}$ & $35 \mathrm{a}$ \\
Overall survival & $53 \mathrm{~b}$ & $67 \mathrm{a}$ & $53 \mathrm{a}$ & $55 \mathrm{a}$ \\
\hline z & Treatment means within rows in each year followed by the same letter are not
\end{tabular}

${ }^{\mathrm{z}}$ Treatment means within rows in each year followed by the same letter are not significantly different $\left(\chi^{2}\right)$ at $5 \%$ level.

\section{Effect of Transplanting Method on Tree Growth and Establishment}

First-year measurements on transplanted eldarica pine trees showed that current-season shoots number and length were significantly greater (32\% and $53 \%$, respectively) for B\&B trees compared to BR trees, whereas leaf chlorophyll content and dieback were not affected by transplanting method (Table 3). In the second year, no significant difference could be observed between growth responses of $\mathrm{B} \& \mathrm{~B}$ and $\mathrm{BR}$ trees.

$\mathrm{B} \& \mathrm{~B}$ and $\mathrm{BR}$ white mulberry trees showed no significant difference in their growth parameters during both first and second year (Table 3).

Despite the high mortality of transplanted smoothleaf elm trees, those B\&B and BR trees that survived showed similar trend in their growth responses, though only dieback on BR trees was significantly $(61 \%)$ greater than B\&B trees (Table 3). In the second year, no significant difference between $\mathrm{B} \& \mathrm{~B}$ and their BR counterparts was noted.

For all three species, $R_{D}$ of $B \& B$ trees was significantly greater than $\mathrm{BR}$ trees during the first year (June to October 2010) (Figure 1). The most pronounced impact of transplanting method was observed for eldarica pine trees with the $\mathrm{RGR}_{\mathrm{D}}$ of $\mathrm{B} \& \mathrm{~B}$ trees being two times higher than that of $\mathrm{BR}$ trees. No significant difference was detected in $R R_{D}$ of $B \& B$ and BR trees during the second year (June to October 2011). 


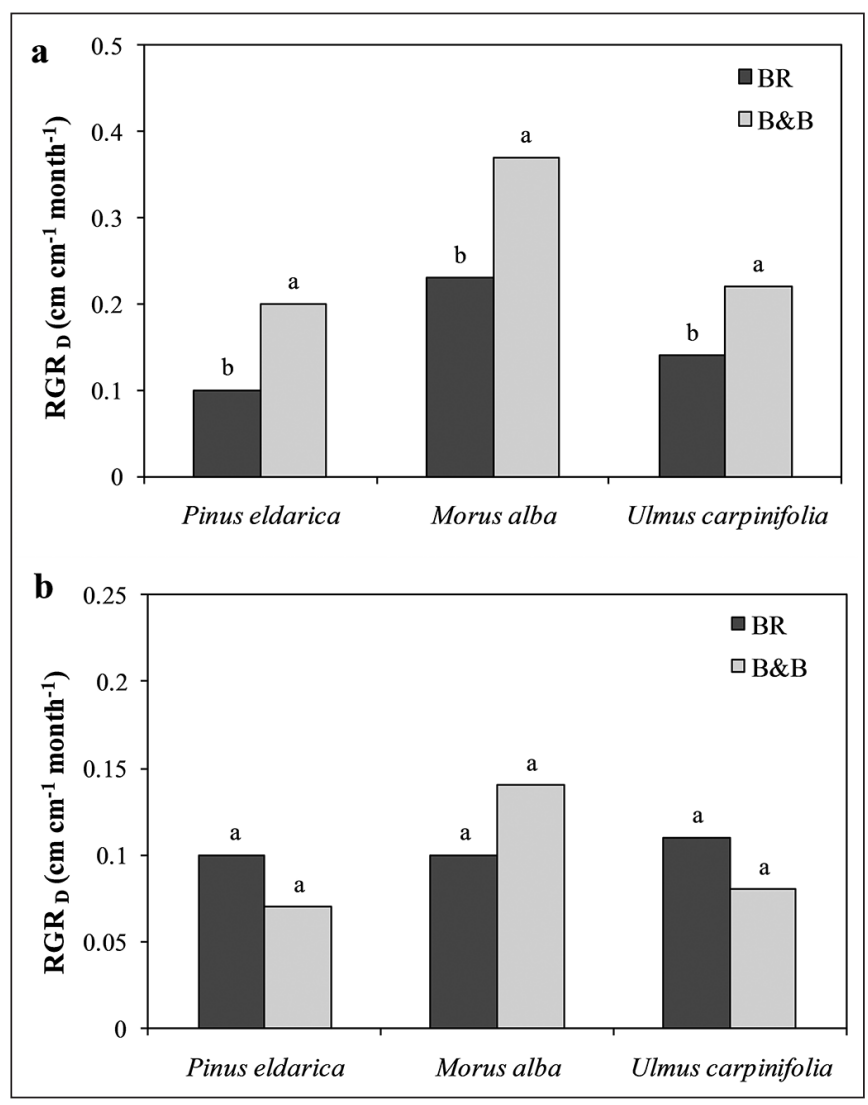

Figure 1. Effect of transplanting method on relative growth rate for trunk diameter (RGR ) of transplanted eldarica pine (Pinus eldarica), white mulberry (Morus alba), and smoothleaf elm (UImus carpinifolia) trees during first (a) and second (b) years after transplanting. Trunk diameter was measured $10 \mathrm{~cm}$ above soil surface. Means followed by the same letter are not significantly different (Duncan's multiple-range test) at $5 \%$ level.

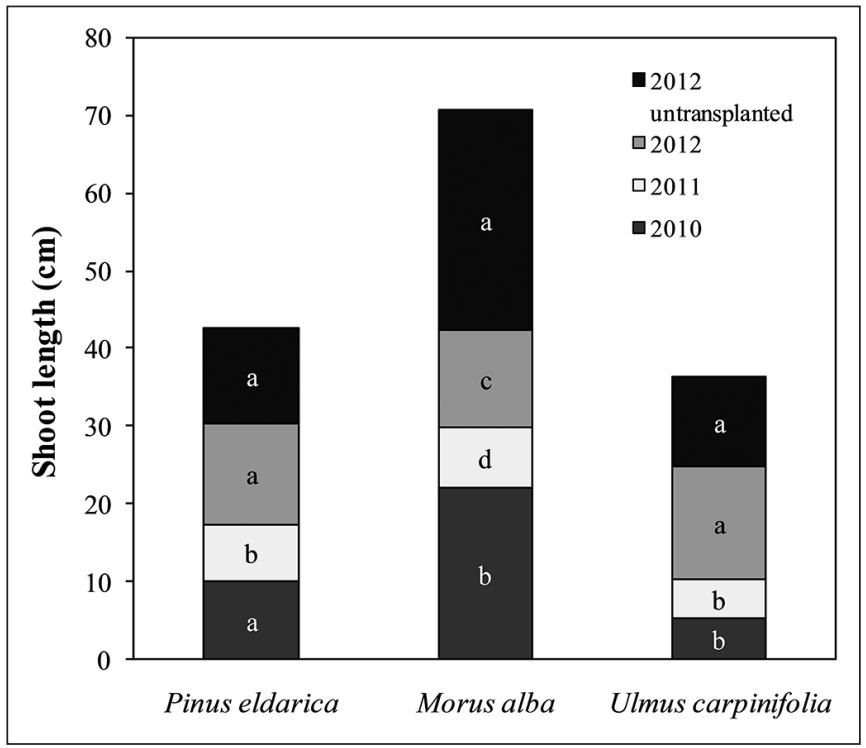

Figure 2. Annual shoot growth of transplanted eldarica pine (Pinus eldarica), white mulberry (Morus alba), and smoothleaf elm (UImus carpinifolia) trees during three years following transplanting. Means followed by the same letter are not significantly different (Duncan's multiple-range test) at $5 \%$ level.
According to the results, current-season shoot growth of eldarica pine and white mulberry trees in the second year was significantly reduced as compared to the first year (Figure 2). This reduction was more pronounced for white mulberry trees where the mean shoot length decreased from $22 \mathrm{~cm}$ in the first year to $8 \mathrm{~cm}$ in the second year. However, a strong increase $(5.7 \mathrm{~cm}, 4.3 \mathrm{~cm}$, and $9.7 \mathrm{~cm}$ for eldarica pine, white mulberry, and smoothleaf elm trees, respectively) was observed in shoot growth of all three species during the third year. It is worth noting that unlike two other species, shoot growth of white mulberry trees in the third year was still statistically lower than that of untransplanted trees, suggesting that this species requires more time for post-transplant establishment.

\section{DISCUSSION}

Transplanting date had significant impact on survival of eldarica pine. The highest percent survival was observed for late-spring-transplanted trees (mean air temperature between $10^{\circ} \mathrm{C}-20^{\circ} \mathrm{C}$ ). This result is in agreement with previous findings asserting one of the appropriate times for transplanting conifers is the early growing season when the temperature is warm enough to permit new root growth to begin immediately after planting (Iles 2001). Late-spring transplanting resulted in significant reduction in tree survival. Furthermore, none of the early-winter-transplanted trees were able to tolerate trans-planting (probably due to restricted root growth and continued transpiration demand from shoots and green leaves). However, this result differs from that of Aref and El-Juhany (2004), who showed that one-year-old Juniperus procera seedlings transplanted early in winter reached $98 \%$ survival after two years following transplanting in temperate climate of southwest Saudi Arabia. Species type, larger size transplanted trees, and drier climate of present study may be reason for the poor results obtained.

White mulberry trees had great capability to tolerate transplanting operation when harvested and dug during the dormant season, since none of the early-winter-transplanted trees were lost by the end of experimental period. Transplanting in warmer ambient temperatures (early and late spring) significantly decreased survival rate. Several benefits have been considered for planting and transplanting deciduous trees during dormant seasons, including cooler temperatures and shorter days that decrease transpiration demand, lignified cells and ceased shoot extension which all reduce water stress (Good and Corell 1982; Richardson-Calfee and Harris 2005). Moreover, dormanttransplanted trees have more time to establish suitable root-tosoil contact before shoot growth in spring (Buckstrup and Bassuk 2000). Although tree species vary in their preferred transplanting date, many deciduous trees have been demonstrated to respond better when transplanted in fall or winter such as Fraxinus pennsylvanica Marsh., Syringa reticulate (Harris and Bassuk 1994), Chionanthus virginicus L. (Harris et al. 1996), and Celtis occidentalis (Buckstrup and Bassuk 2000).

In this study, smoothleaf elm showed a high rate of mortality. Yet, of those survived, early-winter-transplanted trees had significantly greater percent survival than early-spring transplanted trees, suggesting that winter planting was advantageous compared to spring planting. The study authors assume that among contributing factors for high mortality rate of smoothleaf elm trees, the pre-transplant status of these trees is probably the most influential factor, as in recent years, incidence of elm beetle pest (Galerucella 
Table 3. Effects of transplanting method on selected growth parameters of transplanted eldarica pine (Pinus eldarica), white mulberry (Morus alba), and smoothleaf elm (Ulmus carpinifolia) trees during the first (2010) and second (2011) years following transplanting. Measurements were conducted in October of each year.

\begin{tabular}{|c|c|c|c|c|c|}
\hline Species & $\begin{array}{l}\text { Transplanting } \\
\text { method }\end{array}$ & $\begin{array}{l}\text { Shoot } \\
\text { length }(\mathrm{cm})\end{array}$ & $\begin{array}{l}\text { Shoot } \\
\text { number }\end{array}$ & $\begin{array}{l}\text { Dieback } \\
(\mathrm{cm})\end{array}$ & $\begin{array}{l}\text { Chlorophyll } \\
\text { content }^{z}\end{array}$ \\
\hline & & & & & \\
\hline Eldarica pine & BR & $6.9 \mathrm{~b}^{y}$ & $5.8 \mathrm{~b}$ & $3.4 \mathrm{a}$ & $7.5 \mathrm{a}$ \\
\hline \multirow[t]{2}{*}{ White mulberry } & $\mathrm{BR}$ & $19.8 \mathrm{a}$ & $8.6 \mathrm{a}$ & $5.4 \mathrm{a}$ & $16.4 \mathrm{a}$ \\
\hline & $\mathrm{B} \& \mathrm{~B}$ & $19.2 \mathrm{a}$ & $9.1 \mathrm{a}$ & $6.3 \mathrm{a}$ & $16.8 \mathrm{a}$ \\
\hline \multirow[t]{2}{*}{ Smoothleaf elm } & $\mathrm{BR}$ & $7.0 \mathrm{a}$ & $5.0 \mathrm{a}$ & $3.7 \mathrm{a}$ & $13.0 \mathrm{a}$ \\
\hline & $\mathrm{B} \& \mathrm{~B}$ & $6.8 \mathrm{a}$ & $5.0 \mathrm{a}$ & $2.3 \mathrm{~b}$ & $12.6 \mathrm{a}$ \\
\hline \multicolumn{6}{|c|}{2011} \\
\hline \multirow[t]{2}{*}{ Eldarica pine } & $\mathrm{BR}$ & $5.3 \mathrm{a}$ & $5.7 \mathrm{a}$ & - & $10.8 \mathrm{a}$ \\
\hline & $\mathrm{B} \& \mathrm{~B}$ & $4.8 \mathrm{a}$ & $7.3 \mathrm{a}$ & - & $12.4 \mathrm{a}$ \\
\hline \multirow[t]{2}{*}{ White mulberry } & BR & $5.7 \mathrm{a}$ & $8.9 \mathrm{a}$ & - & $12.6 \mathrm{a}$ \\
\hline & $\mathrm{B} \& \mathrm{~B}$ & $7.7 \mathrm{a}$ & $7.8 \mathrm{a}$ & - & $13.2 \mathrm{a}$ \\
\hline \multirow[t]{2}{*}{ Smoothleaf elm } & $\mathrm{BR}$ & $4.3 \mathrm{a}$ & $7.1 \mathrm{a}$ & - & $16.2 \mathrm{a}$ \\
\hline & $\mathrm{B} \& \mathrm{~B}$ & $2.9 \mathrm{a}$ & $5.2 \mathrm{a}$ & - & $17.0 \mathrm{a}$ \\
\hline
\end{tabular}

${ }^{\mathrm{z}}$ For white mulberry and smoothleaf elm trees, mean leaf chlorophyll content was measured by SPAD meter readings, while for eldarica pine trees it was determined spectroscopically and presented as $\mathrm{mg} \mathrm{g}^{-1}$ of fresh weight.

${ }^{y}$ Treatment means within column in each year followed by the same letter are not significantly different (Duncan's multiple-range test) at $5 \%$ level.

luteola) and Dutch elm disease (Ophiostoma novo-ulmi) has severely compromised elm tree growth and vitality in Isfahan. Low survival rate has been reported for trees and shrubs transplanted in dry climates. Transplanted honey mesquite (Prosopis glandulosa) seedlings in the arid Sonoran Desert (California, U.S.) showed $77 \%$ mortality after 3.5 years (Bainbridge et al. 2001).

For all three species, trees planted as $\mathrm{B} \& \mathrm{~B}$ had significantly greater percent survival, suggesting that B\&B transplanting of studied tree species may be less stressful and lead to better establishment than BR transplanting. Nevertheless, conflicting observations have been published on transplanting success of $\mathrm{B} \& \mathrm{~B}$ and $\mathrm{BR}$ trees and it seems to be dependent on tree species and regional climate, in addition to cultural practices and post-transplant care. For instance, B\&B transplanted American hophornbeam (Ostrya virginiana) reached 100\% survival two year after transplanting, while BR trees showed high rate of mortality $(50 \%)$. B\&B transplanted hackberry (Celtis occidentalis) trees also had greater (10\% larger) survival than BR trees, whereas for swamp white oak (Quercus bicolor) no substantial impact was observed for transplanting method (Buckstrup and Bassuk 2000). Most recently, Anella et al. (2008) reported no significant difference in mortality of B\&B and BR stocks of Platanus $\times$ acerfolia, Acer $\times$ freemanii, and Taxodium distichum, in the more drought-inclined environment of Oklahoma, U.S. Similar results on 10 urban street species have been reported by Jack-Scott (2012).

While B\&B transplanting method increased survival rate of studied species compared to BR transplanting, its impact on different growth parameters was less impressive except for trunk diameter. In all three species, B\&B transplanted trees had higher $\mathrm{RGR}_{\mathrm{D}}$ than their BR counterparts. The same result was obtained by Ross (2008), who showed that $\mathrm{B} \& \mathrm{~B}$ transplanted Platanus $\times$ acerfolia trees had significantly greater $R_{G R}$ than $B R$ trees of similar size. Findings of another study on some street tree species agreed with results of present study (Watson et al. 1986).

By the end of second year, most of the significant differences observed for tree survival and growth parameters disappeared. This is consistent with Buckstrup and Bassuk (2000) and Vanstone and Ronald (1981) who found that first year effects of transplanting method did not persist into the second year.

Reduced growth of current-season shoots is one of the most important indicators of transplant shock (Watson et al. 1986; Sturve et al. 2000). This is mainly due to insufficient supply of water and nutrition, as well as reduction in root-produced hormones necessary for vigorous shoot extension (Hinesly 1986). Shoot growth reduction is mostly species dependent and may last for few years following transplanting, until replacement of new root system (Watson et al. 1986; Ross 2008). In the present study, shoot growth significantly decreased during the first two years after transplanting. However, rapid increase in annual shoot growth was observed by the third year, so the growth rate of eldarica pine and smoothleaf elm trees came to equal that of untransplanted tress. Therefore, it seems eldarica pine and smoothleaf elm trees have almost been established during three years, while white mulberry trees require more time for complete establishment.

In the present study, the effect of transplanting date and method on growth and survival of three urban tree species were examined in order to determine the appropriate transplanting conditions of these species. This is crucial for maintaining and protecting valuable urban trees in arid and semiarid climates. Based on the data, early-winter transplanting for white mulberry and smoothleaf elm trees and early-spring transplanting for eldarica pine trees resulted in greater survival rate and are therefore considered as the best time of the year for transplanting the aforementioned trees in the Isfahan landscape. In the first year following transplanting, the $\mathrm{B} \& \mathrm{~B}$ method conferred advantage over BR method for survival of transplanted trees but its impact on different growth indices was not significant. Also, post-transplant growth differences observed between B\&B and BR trees did not continue in subsequent year, suggesting that final performance of BR trees may be equal to their B\&B counterparts. Further research is needed both to understand the long-term effects of the different treatments and also to determine optimal transplanting methods for each species.

Acknowledgments. The authors would like to appreciate Parks and Landscape Organization of Isfahan Municipality for financial support of this research. 


\section{LITERATURE CITED}

Anella, L., T.C. Hennessey, and E.M. Lorenzi. 2008. Growth of balledand-burlapped versus bare-root trees in Oklahoma, U.S. Arboriculture \& Urban Forestry 34:200-203.

Aref, I.M., and L.I. El-Juhany. 2004. Planting Juniperus procera trees in the natural forests of Saudi Arabia: The first trial. The Second Conference for Development and the Environment in the Arab World, Assiut Univ., Egypt. pp. 339-344.

Bainbridge, D., J. Tiszler, R. Macaller, and M.F. Allen. 2001. Irrigation and mulch effects on desert shrub transplant establishment. Native Plant Journal 2:1-5.

Buckstrup, M.J., and N.L. Bassuk. 2000. Transplanting success of balled and burlapped versus bare-root trees in the urban landscape. Arboriculture \& Urban Forestry 26:298-308.

Buckstrup, M.J., and N.L. Bassuk. 2003. Creating the urban forest: The bare root method. Cornell University's Urban Horticulture Institute, Ithaca, New York, U.S. 18 pp.

Bühler, O., P. Kristoffersen, and S.U. Larsen. 2007. Growth of street trees in Copenhagen with emphasis on the effects of different establishment concepts. Arboriculture \& Urban Forestry 33:330-337.

Cool, R.A. 1975. Tree spade vs. bare root tree planting. Journal of Arboriculture 2:92-95.

Dumbroff, E.B., and D.P. Webb. 1978. Physiological characteristics of sugar maple and implications for successful planting. Forest Chronicle 54:92-95.

Good, G.L., and T.E. Corell. 1982. Field trials indicate the benefits and limits of fall planting. American Nurseryman 156:31-34.

Harris, J.R, J. Fanelli, and P. Thrift. 2002. Transplant timing affects early root system regeneration of sugar maple and northern red oak. HortScience 36:805-807.

Harris, J.R., and J. Fanelli. 1999. Root and shoot growth periodicity of pot-in-pot red and sugar maple. Environmental Horticulture 17:80-83.

Harris, J.R., and N.L., Bassuk. 1994. Seasonal effects on transplantability of scarlet oak, green ash, Turkish hazelnut, and tree lilac. Arboriculture \& Urban Forestry 20:310-317.

Harris, J.R., P. Knight, and J. Fanelli. 1996. Fall transplanting improves establishment of balled and burlapped fringe tree (Chionanthus virginicus L.). HortScience 31:1143-1145.

Harris, J.R., R. Smith, and J. Fanelli. 2001. Transplant timing affects first-season root growth of Turkish hazelnut (Corylus colurna L.). HortScience 36:805-807.

Hinesly, L.E. 1986. Effect of transplanting time on growth and development of Fraser fir seedling. HortScience 21:65-66.

Hiron, A.D., and G.C. Percival. 2012. Fundamentals of tree establishment: A review. pp. 51-62. In: Trees, People and the Built Environment. Proc. of Conference on Urban Trees Research. Edgbaston, Birmingham, UK.
Hoffman, W.A., and H. Poorter. 2002. Avoiding bias in calculations of relative growth rate. Annals of Botany 80:37-42.

Iles, J. 2001. Community trees: When to plant? University of Iowa Cooperative Extension Service, Iowa, U.S. 3 pp

Jack-Scott, E. 2012. Survival and growth factors affecting communityplanted urban street trees. Cities and the Environment 4:1-14.

Kelly, R.J., and B.C. Moser. 1993. Root regeneration of Liriodendron tulipifera in response to auxin, stem pruning, and environmental conditions. Journal of the American Society for Horticultural Science 108:1085-1090

Lichtenthaler, H.K. 1987. Chlorophylls and carotenoids, the pigments of photosynthetic biomembranes. pp. 350-382. In: R. Douce and L. Packer (Eds.). Methods Enzymology Academic Press, Inc., New York, New York, U.S.

Milton, S.J., W.R.J. Dean, M.A. Duplessis, and W.R. Siegfried. 1994. A conceptual model of arid rangeland degradation. BioScience 44:70-76.

Richardson-Calfee L.E., and J.R. Harris. 2005. A review of the effects of transplant timing on landscape establishment of field-grown deciduous trees in temperate climate. HortTechnology 15:132-135.

Ross, M. 2008. The influence of initial tree size on growth, canopy development and physiology in urban environment. M.Sc. thesis. Univ. of. Michigan State, Michigan, U.S. 110 p.

Sather, I., E. Macie, and D.R. Hartel. 2004. Urban Forestry ManualBenefits and Costs of the Urban Forest. USDA Forest Service, Southern Center for Urban Forest Research \& Information. Athens, Georgia, U.S. 377 pp.

Sturve, D.K., L. Burchfield, and C. Maupin. 2000. Survival and growth of transplanted large and small caliper red oaks. Arboricultural Journal 26:162-169.

Trowbridge, P.J., and N.L. Bassuk. 2004. Trees in the Urban Landscape. Wiley, Hoboken, New Jersey, U.S. 207 pp.

Vanstone, D.E., and W.G. Ronald. 1981. Comparison of bareroot versus tree spade transplanting of boulevard trees. Arboriculture and Urban Forestry 7:271-274.

Watson, G.W., and E.B. Himelick. 1982. Seasonal variation in root regeneration of transplanted trees. Journal of Arboriculture 8:305-310.

Watson, G.W., and E.B. Himelick. 1997. Principles and practices of planting trees and shrubs. International Society of Arboriculture, Champaign, Illinois, U.S. 199 pp.

Watson, G.W., E.B. Himelick, and E.T. Smiley. 1986. Twig Growth of Eight Species of Shade Trees Following Transplanting. Arboriculture \& Urban Forestry 12:241-245.

Zhang, J., G. Tian, Y. Li, and M. Lindstrom. 2002. Requirements for success of reforestation projects in a semiarid low-mountain region of the Jinsha river basin, southwestern China. Land Degradation and Development 13:395-401. 
Nematollah Etemadi (corresponding author) Department of Horticultural Science, College of Agriculture Isfahan University of Technology

84156-83111

Isfahan, Iran

etemadin@cc.iut.ac.ir

Rezvan Mohammadi Nezhad

Department of Horticultural Science, College of Agriculture Isfahan University of Technology

84156-83111

Isfahan, Iran

Najmeh Zamani

Department of Horticultural Science, College of Agriculture

Islamic Azad University, Khorasgan branch

81551-39998

Isfahan, Iran

Mohammad Mahdi Majidi

Department of Agronomy and Plant Breeding

College of Agriculture

Isfahan University of Technology

84156-83111

Isfahan, Iran
Zusammenfassung. Die größten Herausforderungen bei der Verpflanzung von Bäumen in trockene Regionen im Vergleich zu moderaten Regionen bestehen in der höheren Absterberate und der langsameren Etablierung. An sich können das Datum und die Methode der Verpflanzung potentiell das Überleben und die Etablierung verbessern, genauso wie die subsequente Leistung der verpflanzten Bäume an ariden Standorten. In der gegenwärtigen Studie wurden drei urbane Arten: Eldarica-Kiefer (Pinus eldarica Medw.), Weiße Maulbeere (Morus alba L.) und Feldulme (Ulmus carpinifolia Gled.), die gewöhnlich in Isfahan, Iran verwendet werden von Januar bis Juni 2010 verpflanzt, wo die durchschnittliche Temperatur weniger als $10^{\circ} \mathrm{C}$ (früher Winter), zwischen $10^{\circ} \mathrm{C}$ und $20^{\circ} \mathrm{C}$ (früher Frühling) oder mehr als $20^{\circ} \mathrm{C}$ (später Frühling) beträgt. Die Hälfte der Bäume hatte nackte Wurzeln und die andere Hälfte war Ballenware. Die Maulbeeren und Feldulmen, die früh im Winter verpflanzt wurden, hatten die höchste Überlebensrate nach zwei Jahren. Die beste Überlebensrate bei den Eldarica-Kiefern wurde bei Bäumen beobachtet, die im frühen Frühling verpflanzt wurden. Für alle Arten bei der Ballenware war im ersten Jahr die Überlebensrate und der Zuwachs an Stammdurchmesser deutlich größer als bei Wurzelware. Auch das Trieblängenwachstum im ersten Jahr und die Anzahl der Triebe bei den Kiefern, sowie das Absterben der Ulmen wurden deutlich durch die Verpflanzungsmethode beeinflusst. Im zweiten Jahr waren Wachstum und Überleben bei allen Bäumen und Produktionsmethoden gleich. Das jährliche Trieblängenwachstum bei der Kiefer und Ulme, aber nicht bei der Maulbeere entsprach am Ende des dritten Jahres nach der Verpflanzung dem von unverpflanzten Bäumen und wies damit auf eine artenspezifische Reaktion auf die Etablierung von Bäumen in ariden Regionen hin.

Resumen. Los principales retos para trasplantar árboles en regiones áridas en comparación con las regiones templadas son una mayor mortalidad y menor tasa de establecimiento. Como tal, la fecha y el método de trasplante potencialmente pueden mejorar la supervivencia y el establecimiento, así como el desempeño posterior en el paisaje de los árboles trasplantados en un clima árido. En el presente estudio, tres especies urbanas de uso común en Isfahan, Irán, pino eldarica (Pinus eldarica Medw.), morera (Morus alba L.), y olmo (Ulmus carpinifolia Gled.), fueron trasplantados entre enero y junio de 2010 , cuando la temperatura media es menor de $10^{\circ} \mathrm{C}$ (invierno temprano), entre $10^{\circ} \mathrm{C} \mathrm{y} 20^{\circ} \mathrm{C}$ (primavera temprana), o más de $20^{\circ} \mathrm{C}$ (primavera tardía). La mitad de los árboles fueron a raíz desnuda (BR) y la mitad con bola en arpillera (B\&B). Los árboles trasplantados de morera y olmos a principios de invierno tuvieron el mayor porcentaje de supervivencia en más de dos años. Se observó la mejor supervivencia para pino eldarica en los primeros árboles trasplantados en primavera. Para todas las especies, el incremento de la tasa de supervivencia y el incremento del diámetro del tronco de árboles $\mathrm{B} \& \mathrm{~B}$ fueron significativamente mayores que BR durante el primer año. Además, el crecimiento del primer año y el número de brotes de los pinos, y la muerte regresiva de los olmos, se vieron afectados significativamente por el método de trasplante. Durante el segundo año, el crecimiento de los árboles y la supervivencia de todas las especies fueron similares para B\&B y BR. El crecimiento anual de brotes de pinos eldarica y olmos, pero no en las moreras, igualó a los árboles no trasplantados para el final del tercer año después del trasplante, lo que sugiere una respuesta específica de la especie para el post-trasplante en el clima árido. 